\title{
Martin Luther's Interpretation on Magnificat. Vademecum of Christian Education for Rulers
}

\author{
Maria CURTEAN*
}

Considering the ethical, anthropological and theologicalperspectives on the institution of a secular leader, as they are presented in Martin Luther's writing "Das Magnificat verdeutschet und ausgelegt", (1521) this paper aims to emphasize his contribution to the contemporary political anthropology and European culture. Presenting Mary's canticle as a vademecum of educating secular leaders, Luther highlights the need of spiritual substantiation of the education of the secular leader and identifies mens cordis as the active and reactive center of the human being, from which all counsels and all reigns must be derived. While still preserving parts of mysticism, mystical and ascetic sources for the Christian education of rulers, thus a fragment of the universal Christian tradition, as they were developed and contextualized in Western Europe, this work by Luther could be a significant impulse for the renewal of the dialogue between Lutheran tradition and Orthodoxy.

Keywords: secular leaders, anthropology, Virgin Mary, mens cordis, education

\section{Introduction}

Luther's translation and interpretation of the Magnificat ("Das Magnificat verdeutschet und ausgelegt" $1520-1)^{1}$ is one of the most beautiful and illustrative of his writings concerning his concept of education for rulers. Luther puts the idea of the responsibilities of a political leader in close relationship to his spiritual education, for " «Das Herz des Königs ist in Gottes Hand, der kann es wenden, wohin er will»” (Proverbs 21.1). Thereby, Luther considers the Holy Virgin Mary's canticle (Luke 1.46b-55) as a source for providing inspiration for the rulers, who want to rule well and be helpful lords ${ }^{2}$. Therefore he interprets the canticle in close connection to an old tradition

\footnotetext{
* Maria Curtean, PhD Student, Andrei Şaguna Faculty of Orthodox Theology, Lucian Blaga University Sibiu, Romania. Adress: C-tin Noica Street 58, 550169, Sibiu, Romania; e-mail: mariacurtean11@gmail.com.

1 For this paper I used the German editions: D. Martin Luther, "Das Magnificat verdeutschet und ausgelegt" (1521) in: D. Martin Luthers Werke: Kritische Gesamtausgabe, Weimarer Ausgabe - WA, vol. 2, Hermann Böhlaus Nachfolger, Weimar - Graz, Akademische Drucku. Verlagsanstalt 1966, p. 538-607; and Martin Luther, "Das Magnificat, verdeutscht und ausgelegt, 1521" in Karin Bornkamm, Gerhard Ebeling (eds.), Ausgewählte Schriften, Vol. 2: "Erneuerung von Frömmigkeit und Theologie", $1^{\text {st }}$ edition, Frankfurt am Main, Insel Verlag 1982, p. 115-196.

2 “...die gut regieren und heilsam Herren sein wollen” in K. Bornkamm, G. Ebeling (eds.), Martin Luther, Ausgewählte Schriften, vol. 2, p. 117.
} 
concerning the theology of ruling rooted in Jewish theology as it is expressed in Proverbs 21.1. Luther's preoccupation with Mariolatry is only secondary here, for he stresses the idea of a ruler's heart education with faith according to Virgin Mary's model of faithfulness.

Luther's writing is a "mirror for princes" (Fürstenspiegel) ${ }^{3}$ and belongs to the devotional writings. He dedicated his translation and commentary of the canticle to the Duke John Frederick, the seventeen-year-old son of the Elector John of Saxony, who would himself become the future Elector of Saxony. Thus, the writing begins with a dedication to John Frederick, in which Luther provides information about the context of his work and refers to the main lines of the theology of ruling. Luther's German translation of the Magnificat is followed by an introduction and the commentary of each verse of the canticle and ends with King Solomon's prayer (1 Kings 3, 5-14 $)^{4}$. He builds the entire exegetic edifice on the model of the mystical relationship between the Virgin Mary, Mother of God (Mutter Gottes) ${ }^{5}$ and God, namely between creature and Creator, focusing on how any faithful soul should behave towards God. Therefore, the structure of Luther's commentary seems to follow these two conceptual levels, namely the Creator's level and the human being's level. Concerning the Creator's level Luther emphasizes both God's attributes and God's way of working in the world. Since only He is Creator and "the Most High", ${ }^{6} \mathrm{He}$ does his works within those of high and of low degree. ${ }^{7}$ Therefore the name and fame belong to Him alone. ${ }^{8}$ He works both directly through his arm and indirectly through creatures. Luther understands "the arm of God to be God's own power, according to the Scriptures and it can be known and understood only by faith". ${ }^{9}$ He explains that where there is no faith, God withdraws His arm and works by means of the creatures, usually in hidden ways. Concerning the human level Luther emphasizes that

\footnotetext{
3 For the same period, we can mentione other "mirror for princes" in Europe. For Romanian political space remains notable the work of Neagoe Basarab, Învăţăturile lui Neagoe Basarab către fiul său Teodosie (The teachings of Neagoe Basarab to his son Theodosie) published before 1520. For the western European space, we remind the well-known writing of Desiderius Erasmus, Institutio principis Christiani or The Education of A Christian Prince (1516) translated in Romanian with the title Educarea principelui creștin, Oradea, Ratio et Revelatio 2015, p. 159-283.

4 In: Orthodox Bible: III Kgs. 3. 5-14.

5 Luther often uses in this writing names like "(zarte) Mutter Gottes" or "(hochgelobte) Jungfrau Maria”, i.e. WA 7, p. 545, 27, p. 546, 21 etc.

6 "allerhöchste", in: M. Luther, Ausgewählte Schriften, vol. 2, p. 120; WA 7, p. 547, 14.

7 “...in den hohen und niedrigen Ständen”, Ibidem, p. 117-118;. WA 7, p. 545, 23.

8 M. Luther, Ausgewählte Schriften, vol. 2, p. 157.

9 Ibidem, p. 172.
} 
nobody is creator among people, for they strive after honor, power, wealth, knowledge and whatever is great. Although the two levels, namely the Creator's and the human's levels seem to be antagonistic according to Luther's teaching on original sin, in his commentary he stresses the idea of a faithful soul as a place of meeting God, when the soul acts like the righteous bride in relation to Christ. In this regard, Mary's heart is a model for all Christians and especially for all those "who want to rule well and be helpful lords". ${ }^{10}$

The text was composed and published in two installments (November 1520 - March 1521 and May-June 1521) in the context of the events that marked Luther's life and prefaced a new chapter in the Universal Church History. ${ }^{11}$ On the one hand the writing preserves at the conceptual and linguistic level traces of medieval theology, in which Luther was educated, but on the other hand it contains enunciations of themes that he would develop later in his maturity stage. It follows the series of Luther's great reformation treatises of 1520 (On Good Works, ${ }^{12}$ To the Christian Nobility, ${ }^{13}$ On the Babylonian Captivity of the Church, ${ }^{14}$ On Christian Liberty), ${ }^{15}$ in which he developed "his religious thoughts into an independent theology and working out a broad program of church and secular reforms". ${ }^{16}$

Luther's commentary on the Magnificat was used less compared to other of his writings and used more in connection with Mariology, humbleness, faith, mystique or its literary value. A short overview of this Luther's work is to be found in Luthers-Lexikon. ${ }^{17}$ Bernard Lohse refers to Luther's work, when writing about his view of God and makes a short remark about

\footnotetext{
10 "die gut regieren und heilsam Herren sein wollen", Ibidem, p. 117.
}

11 On January $3^{\text {th }}, 1521$ the pope proclaimed the excommunication of Luther with the bull Decet Romanum pontificem. After a "triumphal procession" to Worms, when Luther was invited to preach everywhere $\left(2^{\text {th }}-16^{\text {th }}\right.$ April 1521$)$, he retracted anything of his teachings. On May $26^{\text {th }} 1521$, after Luther's departure, the imperial ban was declared and back-dated to May $8^{\text {th }}$ "as to create the impression that the entire imperial diet had agreed to it". Then Luther was "abducted" to Wartburg, which he considered his "Patmos". Martin Treu, Martin Luther in Wittenberg: Ein biografischer Rundgang, Wittenberg, Stiftung Luthergedenkstätten in Sachsen-Anhalt 2003, p. 29-31.

12 "Von den guten Werken" (1520), in: WA 6, p. 196-276.

13 "An den christlichen Adel deutscher Nation: Von des christlichen Standes Besserung", WA 6, p. 404-469.

14 "De captivitate Babylonica ecclesiae praeludium", WA 6, p. 497-573.

15 "Von der Freiheit eines Christenmenschen", WA 7, p. 20-38.

16 See: Volkmar Joestel, Martin Treu, Martin Luther: Rebel and Reformer. A Biographical Sketch, Reformation Biographies, $4^{\text {th }}$ edition, Wittenberg, Drei Kastanien 2013, p. 25.

17 Volker Leppin, Gury Schneider-Ludorff (eds.), Das Luther-Lexikon, Regensburg, Bückle \& Böhm 2014, p. 469-470. 
Luther's observation concerning the attempts of the fanatics to derive the right to revolt from the verse of Luke 1.52. ${ }^{18}$ The book "Das Marienlob der Reformatoren" mentiones Luther's remark concerning Mary's royal origin of the David's family ${ }^{19}$ and offers a considerable space for Mary as a singer of God's works ("Lob der Sängerin"). ${ }^{20}$ Among authors interested in Luther's writing we mention C. Burger professor of Vrije University in Amsterdam with his ample studies concerning Luther's interpretation on the canticle: Marias Lied in Luthers Deutung. Der Kommentar zum Magnifikat (Lk 1, 46b-55) aus den Jahren 1520/21, ${ }^{21}$ and "Luther and Müntzer see Mary's Magnificat through Different Spectacles". ${ }^{22}$ Veit Frech wrote in 1993 a thesis entitled Magnificat und Benedictus Deutsch. Martin Luthers bibelhumanistische Übersetzung in der Rezeption des Erasmus von Rotterdam, which was published in $1995 .{ }^{23}$ It is interesting also to mention Edgar Thaidigsmann's study, in which he acknowledges Luther's contribution to the protestant theology and anthropology with the theme of regard. ${ }^{24}$ We should also mention our article "The theme of regard and Christian's ways to be in the world according Martin Luther's writing «Das Magnificat verdeutschet und ausgelegt, $1521 » " 25$ which was inspired in part by Thaidigsmann's study.

\section{Milestones of a theology of secular rulers}

In the dedication that prefaces Luther's commentary on Mary's canticle, he sets out some key ideas of a theology for rulers in close relation to the theological anthropology: 1. "Das Herz des Königs ist in Gottes Hand, der kann

18 Bernard Lohse, Luthers Theologie in ihrer historischen Entwicklung und in ihrem systematischen Zusammenhang, Göttingen, Vandenhoeck \& Ruprecht 1995, p. 228-229.

19 Walter Tappolet, Albert Ebneter (eds.), Das Marienlob der Reformatoren - Martin Luther, Johannes Calvin, Huldrych Zwingli, Heinrich Bullinger, Tübingen, Katzmann 1962, p. 17-18.

20 Ibidem, p. 78-88.

21 Christoph Burger, Marias Lied in Luthers Deutung. Der Kommentar zum Magnifikat (Lk 1, 46b-55) aus den Jahren1520/21 (Spätmittelalter und Reformation, Neue Reihe 34), Tübingen, Mohr Siebeck, 2007, p. 209.

22 Idem, "Luther and Müntzer see Mary's magnificat through different spectacles", in: Politics and Reformations: Histories and Reformations Essays in Honor of Thomas A. Brady, Jr., Leiden, Brill 2007, p. 241-254.

23 Veit Frech, Magnificat und Benedictus Deutsch. Martin Luthers bibelhumanistische Übersetzung in der Rezeption des Erasmus von Rotterdam (Zürker germanistische Studien 44), Bern, Peter Lang 1995.

24 Johannes von Lüpke (ed.), Edgar Thaidigsmann, Einsichten und Ausblicke: Theologische Studien, Berlin, LIT 2011, p. 3.

25 Maria Curtean, “Tema privirii și modalitățile de a fi în lume ale creștinului, după scrierea lui Martin Luther «Das Magnificat verdeutschet und ausgelegt», 1521”, in: Studia Doctoralia Andreiana V (1/ 2016), p. 6-26. 
es wenden, wohin er will" (Proverbs 21.1);26 2. "Denn ein menschlichen Herz, von Natur Fleisch und Blut, ist aus sich selbst leicht vermessen"; ${ }^{27} 3$. "...an der Person eines solchen großen Fürsten vieler Leute Heil liegt"; 28 4. “...daß sie (Oberherren) Gott mehr fürchten als andere, ihn und seine Werke gut erkennen und sorgsam vorgehen" ${ }^{29}$ We notice that in four statements Luther presents the frameworks of governance and the exigencies and temptations that arise from it according to ancient believe. We can also identify here some relations that structure Luhter's conception of governance, which could be relevant to the contemporary political culture of Europe that still calls itself "Christian": ethics-politics, anthropology-politics; theology of history-politics.

Considering the first relation ethics-politics, we stand for the opinion that Luther's conviction of good governance in agreement with the will of God is rooted both in tradition of Old Testament and in St. Paul's theology of ruling (Romans 13). In regard to the relation anthropology-politics, we notice that on one hand Luther states that from the anthropological point of view all people are equal before God, but on the other hand they are different from the social point of view. Their status can influence both the social and spiritual evolution of the other. Moreover, Luther's anthropological excursus can be a source of valuable terms and ideas for the contemporary European political anthropology, re/connecting it with the authority of Pauline writings. The third relation introduces the providential intervention of God in the history of the humanity both directly through his Arm and indirectly through the creatures. Therefore Luther explains the role of the secular rulers and the relations between the person and the office. He also approaches relation between historical and spiritual Israel, referring to the latter one in connection with the theology of the Cross.

The three relationships are gathered around the idea of the education of the prince, every of them showing a complex aspect of secular ruler's office encircled between Heaven and World. Therefore Luther stresses the importance of the spiritual foundation of ruler's education and identifies mens cordis (Luke 1.51) as the active and reactive center of human being. $\mathrm{He}$ highlights both the idea that God created man, therefore his heart is in His hands and the importance of conversion of ruler's heart and mind by following a complex educational process which means reading the living Word of

\footnotetext{
26 Ibidem, p. 116; WA 7, p. 544, 26-27.

27 Ibidem, p. 117; WA 7, p. 545, 5-6.

28 Ibidem, p. 116; WA 7, p. 544, 22.

29 Ibidem, p. 117; WA 7, p. 545, 15-16.
} 
God, meditation on it and the role of the rulers in the history of salvation, praying and experiencing the faith at the school of Holy Spirit according especially to Mary's model.

The idea of "mens cordis" has a long tradition. Hans Hattenhauer explains that Old Testament language speaks about "heart", which was translated also by mind (Verstand) or reason (Vernunft) since the late Antiquity as a result of the influence of Greek philosophy. Therefore, according to Hattenhauer, in $4^{\text {th }}$ century Philosopher Themistius used the words "heart" and "reason" synonymously at the court of Constantinople, ${ }^{30}$ but he was contemporary with St. John Chrysostom and Gregors of Nazianz. ${ }^{31}$ Isidor of Seville said that heart is the place of all thoughtfulness (Ger. Aufmerksamkeit, Lat. sollicitude) und all knowledge (ger. Wissen, lat. scientia). ${ }^{32}$ Lactantiu stays in the same tradition and describes heart as the the place of understanding (Verstand). ${ }^{33}$ We can add that in Eastern Christianity there is a deep theology of nous (intellect) and heart. Wandering nous can be educated by reading, watching and praying ${ }^{34}$ and only a pure heart is able to see. ${ }^{35}$

Luther uses Proverbs 21.1 to support his commentary of the canticle, therefore in connection with mens cordis. Thus, we identify the ancient Jewish root of Luther's theology of ruling. The king does not govern according to his own will, but according to God's will. When Israel speaks about God, he used the image of hand, explains Hattenhauer. God's hands are the image of His power, for He used them in creating the world (see Ps. 102.26 $6^{36}$ etc.) and $\mathrm{He}$ is still using them in the providential work of supporting it. ${ }^{37}$ Thus, Luther preserves the idea that theology of ruling is based both on the theology of creation and of Providence as it was transmitted throughout the Christian tradition. In the Christian West the words about the heart

30 Hans Hattenhauer, "Das Herz des Königs in der Hand Gottes. Zum Herrscherbild in Spätantike und Mittelalter", in: Zeitschrift für Rechtsgeschichte. XCVIII. Kan. Abt., 67(1/1981), p. 5, viewed on 19.09.2016. 0.7767/zrgka.1981.67.1.1 Downloaded from De Gruyter Online on 09.19.2016 via Universitaetsbibliothek Leipzig.

31 Ibidem, p. 18.

32 Isidor von Sevilla, Etymologiarum libri, apud: H. Hattenhauer, "Das Herz des Königs", p. 5 .

33 Lactantius, De opificio Dei, apud: H. Hattenhauer, "Das Herz des Königs”, p. 5.

34 Avva Evagrie Ponticul, Monahul sau Făptuitorul (Praktikos) - O sută de capitole despre viața duhovnicească comentat de schimarhimadrit Gabriel Bunge, Sibiu, Deisis 2016, p. 105.

35 Ibidem, p. 11.

36 Christian Orthodox Bible, Ps. 101.26.

37 H. Hattenhauer, “Das Herz des Königs", p. 5, 7. 
of the ruler were seen more as a sign of heretical Eastern Emperor theology and were not very fructified. However, the idea is recorded at Ambrose, the bishop of Milan, who influenced the conversion of Augustine: "Vox imperatorie nostri Christum resultet, et ilium solum, quem sentit, loquatur: Quia cor regis in manum Dei" ${ }^{38}$ Thomas Aquinas used the words of the proverb (21.1) like an encouragement for those who were under a tyrannical ruler. ${ }^{39}$ Luther seems to use Solomon's words in order to support the idea of fortifying rulers's faith and responsibility in front of God and towards his subjects and get rid of pope's hands. It was the time when it was believed that the king's heart fell in hands of men. Actually, Luther wrote in 1518 about his own heart to his spiritual father Staupitz: "Christus wird sehen, ob das, was ich gesagt habe, das Seine sei oder das Meine, ohne dessen Wink auch der Papst nicht ein Wort reden, noch der König über mein Herz verfügen kann". ${ }^{40}$ For him it was quite clear that one's consciousness is free as he himself proved in front of Diet of Worms before he wrote the second part of his commentary on Magnificat. Along his commentary, especially when he wrote about the second work of God, namely breaking the spiritual pride, he asserts that as much as the truth itself is better than the men among whom it dwells, so much worse are the wise than the mighty and the rich and God is their enemy ${ }^{41}$. His bitter criticism toward the falsely humbleness among the monastic orders and church hierarchy is quite obvious. ${ }^{42}$ Likewise he urges once more about the need of paying great attention to this mens cordis by means of the good example of Mary's heart, and taking the fear of God as rampart. ${ }^{43}$ Therefore Luther advices the young duke to pray himself and not to put his trust in other men's prayers. ${ }^{44}$ Therefore, in the end of his commentary he offers the German translation of Solomon's prayer for example as we have already mentioned.

\section{Magistratus virum ostendit}

The secular leader has a responsibility that goes beyond the common framework of human activities, and although all men are equal before God from

\footnotetext{
38 Ep. 8 (9), MPL 16, Sp. 1014; H. Hattenhauer, "Das Herz des Königs”, note 7, p. 22.

39 Toma de Aquino, De regimine principum, Über die Herrschaft des Fürsten, apud H. Hattenhauer, "Das Herz des Königs", p. 34.

40 Kurt Aland (ed.), Luther Deutsch, vol. II, apud H. Hattenhauer, "Das Herz des Königs", p. 35 .

41 Martin Luther, Ausgewählte Schriften, vol. 2, p. 176.

42 Ibidem, p. 147.

43 Ibidem, p. 194.

44 Ibidem.
} 
the point of view of theological anthropology, their status makes them different and makes people responsible for their deeds. Thus Luther highlights this aspect from the very beginning, drawing attention that: “...obwohl aller Menschen Herzen in der allmächtigen Hand Gottes sind, ist's doch nicht umsonst allein von den Königen und Fürsten gesagt". ${ }^{45}$ While other men's deeds bring benefit or hurt upon themselves alone or upon few others, rulers are particularly appointed to be either harmful or helpful to other people according to the extension of their authority. ${ }^{46}$ Therefore a ruler is a key factor for the destinies of his subjects. The salvation of many people depends on him. On the contrary he can ruin many lives if is ruled by himself in disfavor of God. ${ }^{47}$ At this point Luther's opinion rooted in the ancient tradition of the Old Testament preserve the antic and medieval opinion that good governance is in agreement with the will of God.

We find also relevant to highlight here the relation between ethics and politics that arises from the sentence quoted above, and that unfortunately nowadays plays almost any role in the context of a desacralized European society. However Luther's ethical conception was preserved in the Lutheran tradition and we ought to mention here D. Bonhoeffer's ethical conception, inherited from Luther, but developed in an original way.

For Bonhoeffer, the foundation of ethical behavior is how the reality of the world and how the reality of God are reconciled in the reality of Christ (Ethics, p. 198). To share in Christ's reality is to become a responsible person, a person who performs actions in accordance with reality and the fulfilled will of God (Ethics, p. 224). There are two guides for determining the will of God in any concrete situation: 1) the need of one's neighbor, and 2) the model of Jesus of Nazareth. There are no other guides, since Bonhoeffer denies that we can have knowledge of good and evil (Ethics, p. 231). There is no moral certainty in this world. There is no justification in advance for our conduct. Ultimately all actions must be delivered up to God for judgment, and no one can escape reliance upon God's mercy and grace. ${ }^{48}$

Therefore in order to understand his mission, a ruler should acquire the knowledge of God, for God's will almost always finds itself in opposition to the value system of secular world:

45 Ibidem, p. 116; WA 7, p. 544, 25-26.

46 WA 7, p. 544, $31-545,1$.

47 WA 7, p. 544, 22-24.

48 Internet Encyclopedia of Philosophy. A Peer-Review Academic Resouce, http://www.iep. utm.edu/bonhoeff/, viewed on 15 June 2017. 
Aber die Welt und Menschenaugen tun das Gegenteil. Die sehen nur über sich, wollen ja hoch fahren, wie Spr. 30.13 steht: "Es ist ein Volk, dem seine Augen in die Höhe sehen, und seine Augenbrauen sind in die Höhe gerichtet". Das erfahren wir täglich, wie jedermann nur über sich, zur Ehre, zur Gewalt, zum Reichtum, zur Kunst, zu gutem Leben und allem, was groß und hoch ist, sich bemüht. ${ }^{49}$

The social group gathers around these values, because

wo solche Leute sind, denen hängt jedermann an, da läuft man hinzu, da dient man gern, da will jedermann sein und der Höhe teilhaftig werden, so daß nicht umsonst in der Schrift so wenig Könige und Fürsten als fromm beschrieben sind..$^{50}$

Luther identifies two sorts of regard, namely God's regard, who looks into the depths and man's regard, whose eyes are lifted up (Prov. 30.13) ${ }^{51}$ The eye of the world is blind and its spirit unfaithful. Even among Christians there are people who do not have faith, for they care more of the worldly goods, their idols, then of God; they care more of the creature, then of the Creator. They despise the verse of the canticle: "Er macht die Hungrigen mit allerlei Gütern" (Luke 1.53). The lack of faith makes these people weak, pushing them in the struggle with the care for tomorrow and the fear to become marginalised in society. Moreover the bad way of people's way of regard produces social cleavages, for they are not willing to look into the depth at the faceless crowd and do something to help them.

In these circumstances the social status of a person, in our case the ruler, becomes the fire test of his personality. Luther's idea arises from St. Paul's words "if it is leadership, he must do so with diligence" (Rom. 12.8) ${ }^{52}$ and illustrates it with a sentence of Bias, ${ }^{53}$ one of the wise men of ancient Greece: "Magistratus virum ostendit" ${ }^{4}$. Luther asserts that ruler would be brought to account by God for his status (Stand) and office. Thus if a ruler failed to love his subjects and does not care about their prosperity, but he is dominated by self-seeking and pleasures, then his governance would be for

49 WA 7, p. 547, 19-22; K. Bornkamm, G. Ebeling (eds.), Martin Luther. Ausgewählte Schriften, vol. 2, p. 120.

50 WA 7, p. 547, 22-25. K. Bornkamm, G. Ebeling (eds.), Martin Luther, Ausgewählte Schriften, p. 120.

51 WA 7, p. 547, 17-19.

52 "Wer da regiert, der sei sorgfältig" WA 7, p. 545, 17.

53 See: Horst Beintker, Helmar Junghans et al. (eds.), M. Luther, Tauschenausgabe, 1: Die Botschaft des Kreuzes, Berlin, Evangelische Verlagsanstalt 1984, note 1, p. 71.

54 WA 7, p. 545, 11-12. 
his soul's perdition and no foundation of monasteries, altars or memorials would help him. ${ }^{55}$ The unlimited freedom of a ruler through riches, honor and power, tempt him more than the others, because the honor and power are strong impulses for the wicked. ${ }^{56}$

Luther presents a very suggestive picture of the temptations that assault ruler's heart, comparing it with a citadel or a castle surrounded by enemies:

Denn das große Gut, die große Ehre, die große Gewalt, die große Gunst, dazu die Schmeichler, ohne die kein Herr sein kann, sind gleichsam um eines Fürsten Herz gelegt und bestürmen es: zur Hoffart, zum Vergessen Gottes, zur Mißachtung des Volkes und des allgemeinen Nutzens, zu Wollust, zu Frevel, zu Vermessenheit, zu Müßiggang und kurz zu allem Unrecht und aller Untugend, so daß freilich kein Schloß und keine Stadt so hart belagert und bestürmt werden kann. ${ }^{57}$

Therefore the knowledge of the will of God implies the conversion of human being's mind (mens cordis), that means a new way of relating with God, self, the other and the world as we will see further in the anthropological Luther's excursus. He gives examples from the Scripture, where the rulers were divided into two categories. So, harmful princes are called "lions" (Zeph. 3.3), "dragons" (cf. Jer. 51.34) and "wild beasts", about which God Himself says, they are one of the "four plagues" sent by Him (Ezek. 14.21). At the same time it calls pious and God-fearing princes "angels of God" (1 King, 29.9) and even "gods" (Ps. 81.6). A God-fearing ruler is "a rare bird in heaven", 58 so Luther warns Duke John Frederick that few kings were described as pious in the Scripture. ${ }^{59}$ Even king David, who was the stateliest of the temporal rulers and ruled in agreement with God's command and not after his own reason (Vernunft), repeatedly stumbled. ${ }^{60}$

\footnotetext{
55 WA 7, p. 602, 12-16.

56 “...reichtumb, ehre und gewalt starcke anreitzung und ursach zu den bösen”, WA 7, p. 558, 16-18.

57 K. Bornkamm, G. Ebeling (eds.), Martin Luther, Ausgewählte Schriften, 2, p. 194; WA 7, p. 602, 4-10.

58 In german text: "Ein Fürst - Wildbret im Himmel” WA 7, p. 591, 6, or "Herren und Fürsten sind Wildbret im Himmel", (Wildbret - venison) - Proverb specific to the Middle Ages. It was used to say that a gentlemen or good ruler is something very rare. See: Jacob Grimm, Wilhelm Grimm Deutsches Wörterbuch, http://woerterbuchnetz.de/DWB/?lemma=wildbret, viewed on 19.10.2016, Thesaurus proverbiorum medii aevii - Lexikon der Sprichwörter des romanisch-germanischen Mittelalters, begründet von Samuel Singer, 13, Berlin - New York, Walter de Gruyter 2002, p. 101.

59 WA 7, p. 547, 24-25.

60 WA 7, p. 601, 31.
} 
Luther is conscious that a Christian, in our case a ruler "cannot be without" riches, honor and power, for he lives in the world, anchored in its social and political structures. Therefore Luther condemns neither the values of the world nor its social or political structures. On the contrary, he is convinced that such forms and differences between persons and states must remain on the earth in this life. ${ }^{61} \mathrm{He}$ uses Solomon's words to defend his view: "Gott wiegt die Geister" (Prov. 16.2) ${ }^{62}$ and explaines that: "Er richtet nicht nach dem äußerlichen Ansehen und der Gestalt, ob sie reich, arm, hoch, niedrig sind, sondern nach dem Geist, wie sich der darin halte" ${ }^{63} \mathrm{He}$ emphasizes that Virgin Mary did't say that God destroyed the thrones, but that: "Er setzet die großen Herren von ihrer Herrschaft ab und erhöhet, die da niedrig und nichts sind" (Luke 1.52). ${ }^{64}$ Therefore, God punishes the abuse, for authority (Obrigkeit) Gouvernance (Regierung), power (Gewalt) and seats (Stühle) need to remain as long as the world remains ${ }^{65}$.

\section{The spirit that holds the entire inheritance}

Interpreting the verse of the canticle "Meine Seele erhebt Gott, den Herrn" (Luke 1.46) in relation with 1 Tes. (5.23) ${ }^{66}$, Luther makes an anthropological excursus in order to clarify the structure of man. He asserts that according to St. Paul's text, human being consists of spirit (Geist), soul (Seele) and body (Leib) ${ }^{67}$. He illustrates his statements with an allegory, namely the structure of the sanctuary built by Moses at God's command. The spirit (Geist) is the noblest part of man, for it is able to understand the incomprehensible, invisible, and eternal things. Moreover it is "das Haus, darin der Glaube und Gottes Wort wohnen" ${ }^{68}$. Luther compares it with the sanctum sanctorum, where God used to dwell: "Sein Geist ist das Allerheiligste, Gottes Wohnung im finstern Glauben ohne Licht; denn er glaubt, was er weder sieht noch fühlt noch begreift"69. The faith that dwells the spirit should be powerful and proper according to King David's words: "Herr, mach in mei-

\footnotetext{
61 "Stand" - class, status, level etc. WA 7, p. 592, 14.

62 WA 7, p. 592, 11; K. Bornkamm, G. Ebeling (eds.), Martin Luther, Ausgewählte Schriften, vol. 2, p. 180.

63 WA 7, p. 592, 11-13; K. Bornkamm, G. Ebeling (eds.), Martin Luther, Ausgewählte Schriften, vol. 2, p. 180.

64 K. Bornkamm, G. Ebeling (eds.), Martin Luther, Ausgewählte Schriften, vol. 2, p. 118.

65 WA 7, p. 580, 30-31.

66 WA 7, p. 550, 21-23.

67 Ibidem.

68 K. Bornkamm, G. Ebeling (eds.), Martin Luther, Ausgewählte Schriften, 2, p. 124.

69 WA 7, p. 551, 19-21.
} 
nem Inwendigsten einen richtigen Geist (Ps. 50.11)"70. David speaks about the unbeliever that "Ihr Herz war nicht richtig zu Gott, und ihr Geist war nicht im Glauben zu Gott" (Ps. 77.41)"71. We can notice here the influence of the medieval mystique, preserved in the young Luther's writings.

The soul, although is also a spirit, performs a different function, namely that of animating (giving life to) the body and working through it. Holy Scripture refers to it in terms of "life", for it lives and works without ceasing even in sleep ${ }^{72}$. Unlike the spirit, the soul understands intelligible things, namely things that reason (Vernunft) can understand, for reason is the light of the soul ${ }^{73}$. The soul has sanctum (the Holy) as correspondent, where were seven lamps, namely the all kind of reason (Verstand), discernment (Unterscheidung), knowledge (Wissen) and understanding (Erkenntnis) of the visible and bodily things ${ }^{74}$.

The third part is the body (Leib) ${ }^{75}$ with its members. It is similar to the atrium (Vorhof), for it is opened to all, so that people may see man's deeds and way of life ${ }^{76}$. Thus, body's function is to apply and use what the soul knows and trusts.

Every of this parts are at their turn good or evil, in other words they are spirit or flesh ("Geist- und Fleisch-Sein"), according to the Pauline terminology used by Luther. Luther expresses the dichotomy in binary groups of terms taken from St. Paul's theological anthropology: spiritual (geistlich) / bodily (leiblich), inner man (innerer Mensch)/ outer man (äußerer Mensch), old man (alter Mensch)/ new man (neuer Mensch). In spite of this duality, Luther's vision of man is unitary. In this regard Bengt Hägglund speaks about Luther's "totus-homo-Betrachtung" as a characteristic of his conception of human being ${ }^{77}$.

Luther interprets St. Paul's prayer (1 Thess. 5.23) so: "Nun bittet Paulus: Gott, der ein Gott des Friedens ist, wolle uns heilig machen, nicht in einem Stück allein, sondern ganz und gar, durch und durch, daß Geist, Seele

70 WA 7, p. 550, 31-34.

${ }^{71}$ K. Bornkamm, G. Ebeling (eds.), Martin Martin Luther, Ausgewählte Schriften, 2, p. 124-125.

72 WA 7, p. 551, 3-4.

73 K. Bornkamm, G. Ebeling (eds.), Martin Luther, Ausgewählte Schriften, 2, p. 125.

74 WA 7, p. 551, 22-23.

75 Luther uses the term "body" (Körper), with the same meaning, WA 7, 551, 23.

76 WA 7, p. 551, 23-24.

77 Bengt Hägglund, "Luthers Antropologie", in: Helmar Junghans (ed.), Leben und Werk Martin Luthers von 1526 bis 1546, Festgabe zu seinem 500. Geburstag, I, Göttingen, Vandenhoeck \& Ruprecht 1983, p. 64-65. 
und Lei bund alles heilig sei"78, stressing the need of the steadiness of man's heart. He emphasis the fine Greek words used by St. Paul: "To olocleron pneuma emon", which he interprets as: "euer Geist, der das ganze Erbe besitzt" "The spirit must be faithful, for if it is not, the soul and the whole life of Christian man will fall in error and wickedness, is spite of his good intentions ${ }^{80}$. Like Augustin, Luther states that man's nature is entirely corrupted after Adam's fall and the curse is innate both to his nature and being: "So völlig ist er durch Adams Fall verdorben, daß ihm der Fluch angeboren, geradezu seine Natur und sein Wesen wird" ${ }^{81}$. The prophets often concluded that men are evil, liars, false and blind, so that in the Scripture is no great honor to be called a man:

in der Schrift keine große Ehre ist, ein Mensch zu heißen. Denn es gilt dieser Name nicht mehr vor Gott, denn als ob jemand vor der Welt ein Lügner und Treuloser würde genannt. So völlig ist er durch Adams Fall verdorben" ${ }^{\prime 2}$.

This ruin of the human nature determined man's "perverse" way of hearts sticking to the gifts of God. At this point Luther's conception meets Evagrius of Pontus' view, who sustained that the root of evil, is neither in the visible things nor in the mental representations of them by the intellect through the knowledge, but in the free choice of the intellect that is inclined to evil ${ }^{83}$. Luther teaches that God condemns only the worldly goods abuse, for $\mathrm{He}$ suffers neither it nor the "perverse" way of people's hearts sticking to his gifts, whether spiritual or material, although they are all good and given by Him. If the gifts are good, then man should change not the things, but his way of seeing them, explains Luther in accordance with Matthew 9.2584. In other words Luther insists on the need of the conversion of one's heart and mind. In this regard he gives the example of forefathers, who had not seen something else after their fall in the sin, but their eyes opened and they saw/knew they were naked according to Moses ${ }^{85}$. Riches were no obstacles

78 K. Bornkamm, G. Ebeling (eds.), Martin Luther, Ausgewählte Schriften, vol. 2, p. 126.

79 WA 7, p. 552, 28-29; Martin Luther, Ausgewählte Schriften, vol. 2, p. 126, p. 127.

80 WA 7, p. 553, 4-6.

${ }^{81}$ WA 7, p. 598, 22; K. Bornkamm, G. Ebeling (eds.), Martin Luther, Ausgewählte Schriften, vol. 2, p. 191.

82 WA 7, p. 598, 22; see also "So völlig ist er durch Adams Fall verdorben, daß ihm der Fluch angeboren, geradezu seine Natur und sein Wesen wird”. Ibidem, p. 189.

83 A. E. Ponticul, Monahul sau Făptuitorul, p. 165.

${ }_{84}$ WA 7, p. 563, 6-11.

${ }^{85}$ WA 7, p. 563, 9-11. 
for Abraham, Isaac, and Jacob. The throne was not a hindrance to King David, or the authority for Daniel in Babylon ${ }^{86}$. Another example is that of Esther, the Jewish queen, who in spite of bearing a precious crown ${ }^{87}$, said it was a dirty rag in her eyes ${ }^{88}$. The best example Luther gives is Mary's heart, for it remains simple, firm and equal even after she found herself to be the Mother of God. For her spirit was able to see incomprehensible, invisible, and eternal things, she called God her Savior and salvation, although she has not seen or felt that. She had only a firm faith. For this faith everything is possible (Mk. 9.23 $3^{89}$ :

Der besteht allein. Der kommt auch in die Efahrung göttlicher Werke und dadurch in göttliche Liebe und so in göttliches Lob und den Gesang, daß der Mensch Großes von Gott hält und ihn recht groß macht ${ }^{90}$.

Faith is the condition of good works. Luther never denied works, but he treated them in accordance with two coordinates: the faith to God and the love toward neighbor, as he would say a few monts later in Wittenberg in the eight sermons, explaining that the entire life of a Christian is faith and love. Faith is directed toward God, while love toward the neighbor, and this should be similar to that love we have received from God without our work and merit ${ }^{91}$.

\section{God's providential intervention in history}

Interpreting the 7 th verse oft he canticle, Luther anticipates the ample exposure of his theory of the two Kingdoms (Zwei-Reiche-Lehre/ Regimentenlehre) developed in the writing from 1523 Von weltlicher Oberkeit, wie weit man ihr Gehorsam schuldig sei" ${ }^{92}$. Determinant for this theory was Augustin's theory of "civitas Diaboli (Bürgerschaft des Teufels)" and "civitas terrena (irdische Bürgerschaft)" developed by the bishop of Hippo in the pagan context of his world ${ }^{93}$. Luther developed it in a different personal way, adapting

\footnotetext{
86 WA 7, p. 592, 8; K. Bornkamm, G. Ebeling (eds.), Martin Luther, Ausgewählte Schriften, vol. 2, p. 180 .

87 Est. 14:17.

88 WA 7, p. 563, 13-14.

89 See also: Mt. 17.20.

90 WA 7, p. 554, 6-9; K. Bornkamm, G. Ebeling (eds.), Martin Luther, Ausgewählte Schriften, vol. 2, p. 129.

${ }^{91}$ WA 10, vol. III, p. 13 with the title: "Ein ander Sermon D.M. Luthers: Am Montag nach Invocavit”, in: M. Luther, Ausgewählte Schriften: Aufbruch zur Reformation, 1982, p. 277.

92 WA 11, p. 229-281.

93 Das Luther-Lexikon, p. 788.
} 
it to the $16^{\text {th }}$ century german context, and distinguishing it from the theological tradition of High- and Late Middle Ages connected with Thomas Aquinas and William of Ockham ${ }^{94}$.

The secular authority was instituted by God according to Rom. 13.1-2 and 1 Petru 2.13-14, and there is no authority except by God's appointment. Its mission is to protect its subjects in fear of God, to His praise and for the protection of righteousness and to punish wrongdoers: "Denn darum trägt sie das Schwert, daß manche, die sich nicht an solche götliche Lehre kehren, in der Furcht halte, damit sie den anderen Frieden und Ruhe lassen"95. Therefore Luther views the world divided into two antagonistic parts, namely between the the godly and the wicked ones ${ }^{96}$. God works in both of these groups, but differently. Where He finds faith, He works directly through his Arm, but where there are unbelievers He works through creatures.

Gottes Arm wird in der Schrift genannt seine eigene Gewalt, in der ohne das Mittel der Kreaturen wirkt. Das geht still und heimlich zu, so daß seiner niemand gewahr wird, bis es geschehen ist. So daß diese Gewalt oder der Arm allein durch den Glauben verstanden und erkannt werden kann ${ }^{97}$.

We recognize here the theology of the Cross. Christ performed His mightiest work on the Cross and although He looked powerless, He defeated sin, death, world, hell, devil and the all evil ${ }^{98}$. Therefore sufferance is the fire test for man's spirit. If the spirit is faithful, then God dwells in it, in the darkness of faith, as Luther has already explained. Although He is present in the man who suffers, He can be identified only through faith:

Da läßt er die Frommen kraftlos werden und unterdrückt (...). Und eben darin ist er am stärksten da, so ganz verborgen und heimlich, daß auch selbst die es nicht fühlen, die den Druck leiden, sondern glauben ${ }^{99}$.

Luther illustrates the idea of the faithful spirit with a parable taken from a medieval book. Among three kinds of spirits, the pure bride is only the spirit that is able to say to his bridegroom: "Ich will nicht das Deine, ich will dich selber haben; bist mir nicht lieber, wenn mir wohl ist, auch nicht unlieber,

94 Ibidem.

95 WA 7, p. 590, 6-7; K. Bornkamm, G. Ebeling (eds.), Martin Luther, Ausgewählte Schriften, 2, p.168.

96 Ibidem, p. 172.

97 Ibidem, p. 171-172.

98 WA 7, p. 586, 14-17.

99 K. Bornkamm, G. Ebeling (eds.), Martin Luther, Ausgewählte Schriften, 2, p. 172. 
wenn mir's übel geht"100. Luthers elucidates who are God's beloved people, about who Virgin Mary sings in this canticle. Thus not every despised, tortured, starved or in a lowly estate man is part of this category, but only those who are willing to be in such estate for God's sake or the truth ${ }^{101}$.

God's intervention in the history can be also observed in the history of Jewish people. Ones of the most beautiful pages of Luther's interpretation, approach the theme of God's beloved people. Luther refers to Israel the chosen nation of God, passing from the historical meaning of Israel to the spiritual one, namely the Christian people, the Church. Therefore, he discusses this theme in relationship with the history of salvation that finds its core in the Incarnation of the beloved Son of God. This is the most important of all God's works ${ }^{102}$, about which Virgin Mary speaks in the $9^{\text {th }}$ and $10^{\text {th }}$ verses of her canticle, where she confesses that she is "eine Magd und Dienerin aller Welt" ${ }^{103}$. Thus she confesses that this greatest work happened not for herself, but for the entire Israel's sake ${ }^{104}$. She divides Israel into two parts and referes to the people who believed in Christ, namely that who serves God $^{105}$. Luther explains that serving God, means that somebody lets God be his God and fulfills His work in him ${ }^{106}$. For the other part of Israel rejected Jesus, "hat er (Gott) doch etliche aus ihnen erlesen, damit dem Namen Israel Genüge getan und hinfort ein geistliches Israel gemacht" ${ }^{107}$.

Interpreting the fight between Jacob and the Angel (Gen. 32.25) Luther emphasizes the difference between fleshly birth (fleischlichem Geburt), with which Jews boast themselves and the birth of Spirit. After he was injured by an Angel in his thigh, Jacob received the name of Israel, as a patriarch, who was not more only Jacob, the father of the fleshly children, but Israel, the father of the spiritual children (Geistliche Kinder)." 108 So Luther comes back to the spiritual sens of term "Israel", explaining that it means the chosen nation of God. This Israel is the whole Christianity: "Wir sehen, daß durch Christus die Christenheit mit Gott so vereinigt ist wie eine Braut mit ihrem

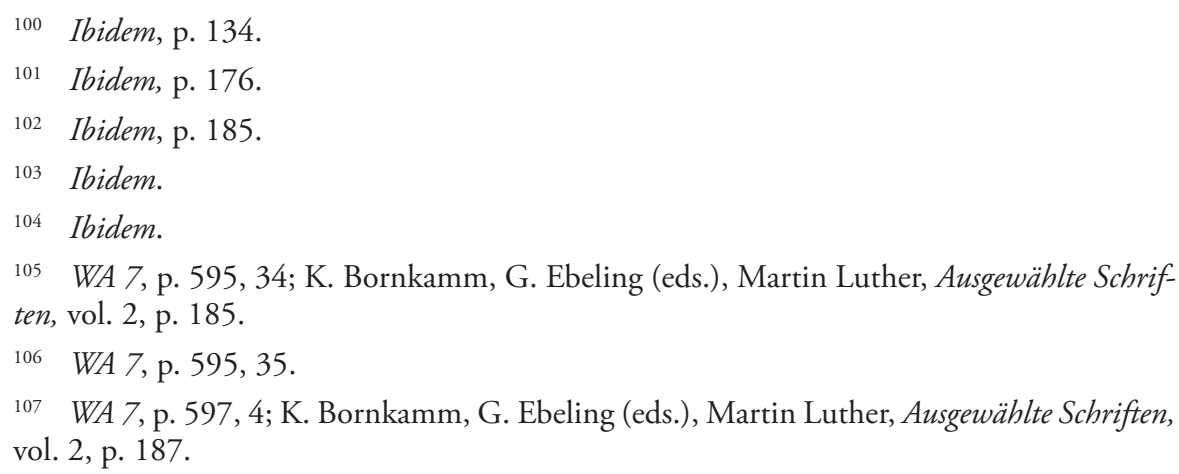

108 WA 7, p. 597, 9. 
Bräutigam, daß die Braut Recht und Macht hat zu des Bräutigams Leib und allem, was er hat. Und das geschieht alles durch den Glauben." ${ }^{109}$ Israel is the chosen race, a royal priesthood, a holy nation, a people of his own, so that you may proclaim the virtues (Tit 2.14; cf. 1 P 2.9). ${ }^{110} \mathrm{He}$ enjoys the fruits of Incarnation, namely salvation from the power of the devil, of sins, of death and of hell and is offered the gifts of justice (Gerechtigkeit), eternal life and salvation. ${ }^{111}$ Although the Christians both coming from the Jews and from the pagans form together this spiritual nation, Luther highlights the difference between them. The Jewish Christians posess the promise, about which Mary refers when she says: "Er gedacht an seine Barmherzigkeit", ${ }^{112}$ while the cause of Christians of the heathen consists of pure grace. ${ }^{113}$

Luther puts the salvation of nation and humanity in relation with the salvation of person, for Israel does not mean only Christianity as a whole, but every Christian apart. Explaining the composition of the word "Israel" from "saar" that means lord, prince and "El" that means God, Luther affirms that Christian man is a prince of God: "Israel ein gottförmiger und gottmächtiger Mensch ist, der in Gott, mit Gott und durch Gott ein Herr ist, alle Dinge zu tun und zu vermögen." 114 Luther stresses this idea in his earlier writings, especially in the treaty On the Freedom of the Christian (1520). ${ }^{115}$ He uses dichotomous terms of the Pauline anthropology, as we have already mentioned above. Therefore, a Christian is flesh and spirit, carnal man and spiritual man old man and new man", ${ }^{116}$ in directly relationship with God, through his living Word and subjected to the secular order.

Following Christ in the world means a way of the Cross. ${ }^{117}$ Luther develops here a former preoccupation of him, as we see in the 94 of his 95 Theses (1517), where he asserted that pursuing Christ implies only suffer-

109 WA 7, p. 597, 13-14; K. Bornkamm, G. Ebeling (eds.), Martin Luther, Ausgewählte Schriften, vol. 2, p. 187.

110 WA 7, p. 596, 21-15.

111 Ibidem.

112 WA 7, p. 597, 30; K. Bornkamm, G. Ebeling (eds.), Martin Luther, Ausgewählte Schriften, vol. 2, p. 185 .

113 Ibidem, p. 192.

114 WA 7, p. 697, 10-12; K. Bornkamm, G. Ebeling (eds.), Martin Luther, Ausgewählte Schriften, vol. 2, p. 187.

115 "Ein Christenmensch ist ein freier Herr über alle Dinge und niemandem untertan. Ein Christenmensch ist ein dienstbarer Knecht aller Dinge und jedermann untertan", in: M. Luther, Ausgewählte Schriften, p. 239.

116 B. Hägglund, "Luthers Antropologie”, p. 64

117 Thesis 94 in WA 1, p. 238, 18-19. 
ings, death and hell. ${ }^{118} \mathrm{He}$ also spoke in the Heidelberg Disputation (1518) about the "theologus crucis" ${ }^{119}$ Here in the commentary on Mary's canticle he puts the theology of the Cross in a relationship with the theme of seeing (Ansehen) and declares that:

Darum hat Gott auch den Tod auf uns alle gelegt und das Kreuz Christi mit unzähligen Leiden und Nöten seinen allerliebsten Kindern und Christen gegeben, ja läßt sie auch zuweilen in Sünde fallen, auf daß er ja viel zu sehen hätte in die Tiefe, vielen helfen, viel wirken, sich als ein rechter Schöpfer erzeigen und damit sich so bekannt machen, daß man ihn liebt und lobt. ${ }^{120}$

Christians form the lowest part of humanity and they are named in the Scripture "paupers, ${ }^{121}$ afflicti, ${ }^{122}$ humiliate, ${ }^{123 "}$ namely poor (arme), null (nichtige), rejected people (verworfene Leute ${ }^{124}$ ). Therefore, "Die Christenheit liegt in der Tiefe und ist unangesehen vor der Welt. Darum sieht Gott sie an", ${ }^{125}$ for God chooses what the world throws out.

\section{Education of man's heart}

Luther has already exposed the social, ethical, anthropological and theological aspects concerning the office of a ruler. In his opinion the most important thing in regard with a good gouvernance is the education of the person who will rule. At this point Luther highlights the spiritual foundation of the political leader's education, finding at its core the education of man's heart and mind, expressed in Mary's canticle by mens cordis (Luke. 1.51). It is a process that consists of reading the living Word of God, meditating both on it and on the role of the rulers in the history of salvation, praying and experiencing the joy through faith at the school of Holy Spirit, according to Mary's model, as we have antipated in the beginning of the paper.

Luther's writing offers a possible model of the spiritual educational process of the $16^{\text {th }}$ century german space. We see here the classical

\footnotetext{
118 Ibidem.

119 Das Luther-Lexikon, p. 168.

120 WA 7, p. 548, 12-13; K. Bornkamm, G. Ebeling (eds.), Martin Luther, Ausgewählte Schriften: Erneuerung, p. 121.

121 "Pauper", -eris (lat.): poor, wihout fortune; 2. modest, etc., in: Gheorghe Guțu, Dicționar Latin-Român, Bucarest, Humanitas 2003; see also: WA 7, p. 560, 15.

122 "Afflictus" (lat.): 1. (p. pf. vb. affligo), Gh. Guțu, Dicționar Latin-Român.

123 From the vb. "humilio" (lat.), Ibidem.

124 "Verworfene Leute" ( $\approx$ "abiectus" lat.), Ibidem.

125 WA 7, p. 560, 26-27; K. Bornkamm, G. Ebeling (eds.), Martin Luther, Ausgewählte Schriften, 2, p. 138.
} 
apprenticeship relationship between spiritual master and his disciple. Therefore, Luther plays the role of the translator (in proper sense) and interpretor of the living Word of God into German for his disciple. The title of Doctor of Holy Scripture (doctor Scripturae, since 1512) gave him the authority to teach the Word of God and protect the Church from the false teachings. At the time "these more "ordinary" doctoral degrees, awarded by theological faculties, were still seen as highly significant ecclesial positions, related to the authoritative "Spirit-led» teaching of the Faith and were awarded under the papal seal, showing their strong connection to the doctores ecclesiae". ${ }^{126}$ Later John Frederick would call Luther his spiritual father.

The other subject of this relationship is Duke John Frederick, the seventeen-year-old son of the Elector John of Saxony, who would later become himself elector of Saxony and one of the "lutherischen Fürsten". ${ }^{127}$ Luther consider that thouse who are meant to be good rulers, should behave differently from the common people. Hence, he told the young man that it would be properly for a prince to obey the faith hearing the Word of God. $\mathrm{He}$ would rather listen to this canticle, then to a wordly song: "Laß einen andern zuhören seinem Mädchen, die ein weltlich Lied singt. Dieser züchtigen Jungfrau hört billig zu ein Fürst und Herr, die ihm ein geistliches, reines, heilsames Lied singt"128. Therefore Holy Virgin Mary's canticle becomes a vademecum for the future ruler and she is indicated as a model of humbleness, because in spite of being exalted above all creatures, she remained serene and simple in her heart. We notice here the term "gelassen" (part./adj. of the verb "lassen"), with the meaning of "calm", "serene", "peaceful" etc., reminding of the noun "Gelassenheit" inherited by Luther from german mystique with the meaning of peace, peace of the soul, tranquility, self-entrusting to the will of God. ${ }^{129}$

In this spiritual educational process, Holy Scriptures play an active role. From the very beginning Luther says that he could not find any more excuse to postpone the translation and interpretation of Mary's canticle, in order not to hinder the "youthful spirit" to meet the living Word of God:

\footnotetext{
126 Stephen Pietsch, "Ego etiam sum doctor scripturae: an historical and contemporary reflection on Luther's life and work as "doctor of holy scripture»", in: Lutheran Theological Journal 48 (3/2014), p. 145-159.

127 Das Luther-Lexikon, p. 320-321.

128 WA 7, p. 545, 22-25.

129 WA 7, p. 555, 34; Horst Beintker, Helmar Junghans et al. (eds.), Martin Luther, Tauschenausgabe, 1, note 12, p. 83, see also: Etymologisches Wörterbuch, http://www.dwds.de/, accessed on 19.10.2016.
} 
der Befehl fernerer Ausrede nicht am Platze sein; denn sonst versäume E.F.G. junges Gemüt, daß es zur Liebe göttlicher Schrift geneigt und durch weitere Übung derselben mehr erhitzt und gestärkt würde. ${ }^{130}$

The contact with the text of the Scripture means getting in touch with Christ himself, the incarnated Word of God. A few months later in the second of the Eight Invocavit Sermons, on March 10, 1522, Luther asigns Christ as the Word of God, who created heaven and earth and all things (Ps. 33:6) with the power of working, fulfiling the preached word and converting a people's heart and mind: “...denn Gott tut das alleine und macht, daß das Wort im Herzen lebt (...). Denn das Wort hat Himmel und Erde geschaffen und alle Dinge, daß muß es tun...”. ${ }^{131}$ We can assume that in Luther's conception is that where Christ is present the Holy Spirit works, too. He is "the true interpreter" as Luther says in a sermon of the maturity stage:

Zum Verständnis der Heiligen Schriften gehört die Offenbarung, daß der Heilige Geist, als der rechte Ausleger, das Wort auswendig durch die mündliche Predigt und inwendig durch Erleuchtung im Herzen erkläre. ${ }^{132}$

In the same sermon interpreting the episod of the two disciples on their way to Emmaus, he emphasises the relation between Christ and the Holy Spirit:

Wir sollen die Heilige Schrift und Gottes Wort gern lesen, hören und behandeln. Den dazu gibt der Heilige Geist, der durchs Wort kräftig ist, Verständnis, wie wir hier an diesen Jüngern sehen: die redden aud dem Wege von der Schrift, und wollten gern hinein, können aber nicht hineinkommen. Da gesellt sich der Herr zu ihnen und tut ihnen eine herrliche Predigt, nimmt Sprüche aus Mose, Propheten und Psalter und erklärt die, so daß sie die Schrift verstehen. ${ }^{133}$

The meeting with living God in the text of the Scripture produces the prayer. Luther offers John Frederick King Solomon's Royal Prayer (1 Kings 3:5-14) as a prayer model for the rulers and lords. Looking into Lutheran tradition, we notice that Luther's christocentrical view on the Scripture and prayer was well preserved in Bonhoeffer's conception about praying through the words

\footnotetext{
130 K. Bornkamm, G. Ebeling (eds.), Martin Luther, Ausgewählte Schriften, 2, p. 116.

131 Ibidem, p. 278-280.

132 WA 37, p. 363-367, Sermon from 1534; Zweiter Ostertag (Lk. 24.13-35), in Martin Luther, Die Predigten, Kurt Aland (ed.), Stuttgart, Ehrenfried Klotz - Göttingen, Vandenhoeck \& Ruprecht 1965, p. 195.
}

133 Ibidem. 
of the Bible, in particular of the Psalms, which could be relevant to the contemporary Christian, too:

Wenn wir daher die Gebete der Bibel und besonders die Psalmen lessen und beten wollen, so müssen wir nicht zuerst danach fragen, was sie mit uns, sondern was sie mit Jesus Christus zu tun haben. Wir müssen fragen, wie die Psalmen als Gottes Wort verstehen können, und dann erst können wir sie mitbeten (...). Nicht die Armut unseres Herzens, sondern der Reichtum des Wortes Gottes soll unser Gebet bestimmen. Wenn also die Bibel auch ein Gebetbuch enthält, so lernen wir daraus, daß zum Worte Gottes nicht nur das Wort gehört, das er uns zu sagen hat, sondern auch das Wort, das er von uns hören will, weil es das Wort seines lieben Sohnes ist. Das ist eine Gnade, daß Gott uns sagt, wie wir mit ihm sprechen und Gemeinschaft haben können. Wir können es, indem wir im Namen Jesu Christi beten. ${ }^{134}$

Therefore by exercising his mind in the Scripture, the young man is introduced in the faith. His mind "erhitzt und gestärkt würde", leaving the "perverse" way of sticking to the gifts of God, whether spiritual or material, as we have already seen above, for all things are possible to him that believes (Mc. 9.23). The Lutheran view seems similar again to Evagrius Ponticus conception, who recommends the reading of Holy Scriptures, which testifies, that Christ is not only the Savior of the world, but also the Creator. In other words the Scriptures testify that knowledge that satisfies the needs of the intellect, because it contributes to the pure prayer ${ }^{135}$. Moreover Evagrius recommended acknowledging the One who gave the gifts (the grace and righteousness), namely the Creator. ${ }^{136}$

Thus the purpose of the educational effort is the acquirement of faith in God and knowledge of Him, in other words the conversion of the innermost of the human being. The model proposed by Luther is Mary's heart, which remained steadfast both in riches and in poverty, and did not stick to the gifts of God. Her spirit was like the right bride, ${ }^{137}$ who speaks to Christ so: "Ich will nicht das Deine, ich will dich selber haben; bist mir nicht lieber, wenn mir wohl ist, auch nicht unlieber, wenn mir's übel geht". ${ }^{138}$ Virgin

\footnotetext{
134 Dietrich Bonhoeffer, Gemeinsames Leben. Das Gebetbuch der Bibel, $3^{\text {rd }}$ edition, CHR. Kaiser Verlag 2008, p. 108-109.

135 A. E. Ponticul, Monahul sau Făptuitorul, p. 106.

136 Ibidem, p. 156.

137 The parable used by Luther comes from a book of Christian parables (Strassburg, 1487); Horst Beintker, Helmar Junghans et al. (eds.), Martin Luther, Tauschenausgabe, note 13, p. 85.

138 K. Bornkamm, G. Ebeling (eds.), Martin Luther, Ausgewählte Schriften, vol. 2, p. 134.
} 
Mary came to the knoledge of God and of His works, following the the steps of the process, about which Luther speaks using a similar tone to that of the $4^{\text {th }}$ Evangel: "Es kann niemand jemals Gott loben, er habe ihn denn zuvor liebt. So kann ihn niemand lieben, er sei ihm denn aufs liebste und allerbeste bekannt". ${ }^{139}$ Luther emphasises here the Holy Spirit's work, in order that a person can understand right the Word of God:

Denn es kann niemand Gott noch Gottes Wort recht verstehen, er habe es denn unmittelbar von dem heiligen Geist. Niemand kann's aber von dem heiligen Geist haben, er erfahre es, versuche es und empfinde es denn. Und diese Erfahrung lehrt der heilige Geist als in seiner eigenen Schule. ${ }^{140}$

Virgin Mary attended this "school", being taught the great art and wisdom. ${ }^{141}$ Using the past participle of the verb "verzücken", Luther speaks about an ecstatic experience of Holy Vergin Mary: "Das Wort geht daher aus großer Inbrunst und überschwenglicher Freude, in der sich ihr Gemüt und Leben ganz erhebt von innen heraus im Geist" ${ }^{142}$ Therefore the words of the canticle are few, but great and deep that nobody can understand them, except for the one who felt at least in part the same Spirit. ${ }^{143}$

\section{Conclusions}

Luther's translation in German and interpretation of Virgin Mary's canticle (Lc. 1.46b-55) is a valuable Christian contribution to the contemporary political anthropology and culture, which although is limited to the sociopolical and theological 16th century German context, contains several lines of continuity regarding both exigencies and challenges of the leadership function and a deep understanding of man. The importance of this writing is that Luther highlights the spiritual foundation of the political leader's education. His realism is seen in the fact that he identifies mens cordis as the active and reactive center of the human being, calling it reason (Vernunft), the good mind or he right thought, from which all counsels and all reigns must be derived. He understands that the education of the prince has as its core the education of that mens cordis, in other words the conversion of the

\footnotetext{
139 WA 7, p. 548, 4; Bornkamm, G. Ebeling (eds.), Martin Luther, Ausgewählte Schriften, vol. 2, p. 121.

140 WA 7, p. 546, 24-29; K. Bornkamm, G. Ebeling (eds.), Martin Luther, Ausgewählte Schriften, vol. 2, p. 119.

141 WA 7, p. 546, 31; K. Bornkamm, G. Ebeling (eds.), Martin Luther, Ausgewählte Schriften, vol. 2, p. 119.

142 WA 7, p. 550, 2-3.

143 WA 7, p. 571, 25-26.
} 
heart, in a dynamic process of interaction with God's Creator Word, and experience at the school of the Holy Spirit, in order to acquire discernment and faith, conditions of an efficient and realistic work in the world. The most important model that Luther offers to the future ruler is the humble, steady and joyful heart of the Mother of God, the one in which "the overwhelming Kingdom of God has united with its profound poverty". Preserving the mystical and ascetic source of Christian education, thus a fragment of the universal Christian tradition, as it developed and contextualized in the West of Europe, Luther's work offers bridges for dialogue with Orthodoxy. 